\title{
Age and seasonal variation of serum vitamin $D$ levels in healthy school children and adolescents
}

\author{
Min Sun Kim", You Jean Yang, Pyoung Han Hwang, Dae-Yeol Lee \\ From 7th APPES Biennial Scientific Meeting \\ Nusa Dua, Bali. 14-17 November 2012
}

\section{Purpose}

Vitamin D is an important fat-soluble vitamin that functions as a prohornone and affects bone mineralization and calcium homeostasis. In this study, we measured serum vitamin D levels in healthy school children and adolescents, and evaluated the prevalence of vitamin D defficiency, and its correlation with age, season and other clinical parameters.

\section{Methods}

We included 706 school children and adolescents aged 7 to 18 years (434 girls and 272 boys) from March 2011 to February 2012. We excluded subjects with any acute or chronic diseases. None of subjects were taking calcium or vitamin D supplements. They were classified according age (elementary school, 7-12 years old, $\mathrm{n}=565$; middle school, 13-15 years old, $\mathrm{n}=75$; high school, $16-18$ years old, $n=36$ ), sex (boys, $n=272$; girls, $n=434$ ) and season (spring, March to May, $\mathrm{n}=267$; summer, June to August, $\mathrm{n}=106$; fall, September to November, $\mathrm{n}=139$; winter, December to February, $\mathrm{n}=194$ ). We performed anthropometric measurement and laboratory tests including fasting lipid profile (cholesterol, triglyceride and LDL cholesterol), ALP, Ca, P and serum $25 \mathrm{OHD}_{3}$ level. Vitamin D deficiency were defined as a serum $25 \mathrm{OHD}_{3}$ level lesser than $20 \mathrm{ng} / \mathrm{mL}$.

\section{Results}

1) In total 706 subjects, mean serum vitamin $D$ level was $16.30 \pm 6.10 \mathrm{ng} / \mathrm{mL}$, and prevalence of vitamin $\mathrm{D}$ defficiency was $74.5 \%$. The serum vitamin D level was negatively correlated with age, serum estradiol and $\mathrm{LH}$ values.

2) Mean serum vitamin $D$ levels were $16.65 \pm 6.07 \mathrm{ng} /$ $\mathrm{mL}$ in elementary school group, $15.23 \pm 6.37 \mathrm{ng} / \mathrm{mL}$ in middle school group, and $12.65 \pm 5.56 \mathrm{ng} / \mathrm{mL}$ in high school group. The prevalence of vitamin D deficiency in 3 aged groups was $72.9 \%$ in elementary school group, $78.7 \%$ in middle school group, and $91.7 \%$ in high school group. However, in elementary school group, there was no significant difference in vitamin D levels between low grade (7-9 years old) and high grade subjects (1012 years old).

3) The level of serum vitamin $D$ was significantly higher in summer $(20.99 \pm 6.40 \mathrm{ng} / \mathrm{mL})$ and fall $(19.11 \pm 6.11 \mathrm{ng} /$ $\mathrm{mL})$ than in spring $(15.46 \pm 5.22 \mathrm{ng} / \mathrm{mL})$ and winter $(12.88 \pm 4.37 \mathrm{ng} / \mathrm{mL})$. The prevalence of vitamin $\mathrm{D}$ deficiency was $93.8 \%$ in winter and $49.1 \%$ in summer.

4) Mean serum vitamin $D$ level was significantly lower in girls $(15.73 \pm 5.71 \mathrm{ng} / \mathrm{mL})$ than in boys $(17.20 \pm 6.59$ $\mathrm{ng} / \mathrm{mL}$ ). The prevalence of vitamin D deficiency was $68.8 \%$ in boys and $78.1 \%$ in girls.

\section{Conclusion}

The prevalence of vitamin D deficiency in healthy school children and adolescent was very high, especially in high school adolescents and winter season. These findings suggest that adequate outdoor activity and vitamin D supplements should be necessary for school children and adolescents.

Published: 3 October 2013

doi:10.1186/1687-9856-2013-S1-P159

Cite this article as: Kim et al.: Age and seasonal variation of serum vitamin D levels in healthy school children and adolescents.

International Journal of Pediatric Endocrinology 2013 2013(Suppl 1):P159. 